УДК 334.72:[005.921:005.51]:339.138

Levytskyi Viktor,

PhD in Economics, Associate Professor, Department of management, Lutsk; ORCID ID 0000-0001-8695-9690, e-mail: lewiktor@gmail.com

https://doi.org/10.29038/2411-4014-2020-03-84-91

\title{
MARKETING CONCEPT OF THE MANAGEMENT STRATEGIC PLANNING ENTERPRISE ACTIVITY
}

In the article describes the main problems formation marketing concept of the management strategic planning enterprise activity. Determined that strategic planning for the enterprise is defined as an organized process of strategic decision-making, the main contents of which is to compare own capabilities with the opportunities and threats of the external environment on the basis of the analysis information and determine its marketing orientation. In addition, in this article formed structure marketing concept of the management strategic planning activity enterprise and the proposed conceptual scheme of the management strategic planning activity enterprise that allows us to make decisions most relevant to the requirements of the dynamic external environment. In the paper also substantiated a methodical approach to setting up a marketing information system basis of effective model building marketing information system of the enterprise.

Key words: concept, marketing, management, enterprise, strategic planning, enterprise activity.

Левицкий Виктор, кандидат экономических наук, доцент, Восточноевропейский национальный университет имени Леси Украинки, кафедра менеджмента, г. Луцк

\section{МАРКЕТИНГОВАЯ КОНЦЕПЦИЯ УПРАВЛЕНИЯ СТРАТЕГИЧЕСКИМ ПЛАНИРОВАНИЕМ ДЕЯТЕЛЬНОСТИ ПРЕДПРИЯТИЯ}

В статье рассмотрены основные проблемные вопросы формирования маркетинговой концепции управления стратегическим планированием деятельности предприятия. Определено, что стратегическое планирование на предприятии есть организованным процессом принятия стратегических решений, основным содержанием которого является сопоставление собственного потенциала с возможностями и угрозами внешней среды на основе анализа информации с определением его маркетинговой ориентации. Кроме того, в статье сформирована структура маркетинговой концепции управления стратегическим планированием деятельности предприятия и предложена концептуальная схема управления стратегическим планированием деятельности предприятия, которая позволяет принимать решения максимально соответствующие требованиям динамичной внешней среды. В исследовании также обоснованно методический подход к настройке маркетинговой информационной системы через реализацию эффективной модели построения маркетинговой информационной системы предприятия.

Ключевые слова: концепция, маркетинг, управление, предприятие, стратегическое планирование, деятельность предприятия.

Левицький Віктор, кандидат економічних наук, доцент, Східносвропейський національний університет імені Лесі Українки, кафедра менеджменту, м. Луцьк

\author{
МАРКЕТИНГОВА КОНЦЕПЦЇ̈Я УПРАВЛІННЯ СТРАТЕГІЧНИМ \\ ПЛАНУВАННЯМ ДІЯЛЬНОСТІ ПІДПРИЕМСТВА
}


В статті розглянуто основні проблемні питання формування маркетингової концепції управління стратегічним плануванням діяльності підприємства. Визначено, що стратегічне планування на підприємстві визначається як організований процес ухвалення стратегічних рішень, основним змістом якого є зіставлення власного потенціалу з можливостями та загрозами зовнішнього середовища на основі аналізу інформації та визначення його маркетингової орієнтації. Досліджено, що маркетингова орієнтація в стратегічному плануванні діяльності підприємства реалізується на основі запропонованої маркетингової концепції, яка полягає в адаптації та використанні апробованих методів (інструментів) маркетингу для цілей становлення й проведення процесу стратегічного планування на вітчизняних підприємствах. Крім того, у статті сформовано структуру маркетингової концепції управління стратегічним плануванням діяльності підприємства та запропоновано концептуальну схему управління стратегічним плануванням діяльності підприємства, що дозволяє спрямувати процес дослідження при ухваленні рішень у сторону максимальної відповідності вимогам динамічного зовнішнього середовища. Поряд із дослідженням складових маркетингової концепції управління стратегічним плануванням діяльності підприємства нами сформовано комплекс ознак визначення стратегічного рівня підприємства, що засновані на попередній оцінці готовності менеджменту підприємства до роботи в умовах стратегічного планування. Враховуючи вищезазначені особливості поняття ознак стратегічного рівня підприємства, нами у статті визначено 8 просторів, у межах яких може бути проведено стратегічне планування діяльності підприємства на основі маркетингової концепції. У статті також обгрунтовано методичний підхід до налаштування маркетингової інформаційної системи для вирішення аналітичних завдань стратегічного планування через формування та реалізацію маркетингової концепції. Тим самим істотно розширені можливості використання аналітичної функції маркетингу, що підвищує якість процесу стратегічного планування та допомагає інформаційно-аналітичному забезпеченню процесу управління стратегічним плануванням на основі концепції маркетингу реалізуватись у ефективній моделі побудови маркетингової інформаційної системи підприємства.

Ключові слова: концепція, маркетинг, управління, підприємство, стратегічне планування, діяльність підприємства.

Formulation of the problem. In the modern economics development of enterprises based on orientation of company activities on customer needs is the only comprehensive method of doing business in a competitive market. However, despite many years of scientific studies and the experience derived from the activities of enterprises, many of them do not know how to implement the process of developing and building effective marketing concept into practice.

It is understood that explore the concept of marketing is one thing, but to remain faithful to this philosophy and implement it into practice is quite another. Therefore, the above problems of the development of the marketing system of the management of enterprise activity the characterized by full absence of integrated marketing concept of the management strategic planning of enterprise activity, which a its typical for european business, therefore the necessity of its use on the modern Ukrainian enterprises increases significantly.

The analysis of researches and publications. Methodological and technological issues of organization strategic planning, strategic marketing and marketing consulting is dedicated to many publications. Among foreign scientists it should highlight the work of scholars such as: R. Akoff, I. Ansoff, H. Wissema, P. Doyle, J-J. Lambin, F. Kotler, G. Koch, M. McDonald, M. Porter [5,7].

It should also highlight a fairly detailed consideration of various aspects of the strategic planning process in the works of such scientists us: G. Azoev, G, Bagiev, M. Butko, Ye. Golubkov, O. Kuzmin, L. Lipich, T. Pichugina, N. Podolchak, R. Fatkhutdinov[1, 3, 4, 8-10].

At the same time at the moment no studies, which comprehensively presents the methodology of strategic planning of activity of the enterprise on the basis of the principles of marketing. Even in the periodic studies, the problem of the use of marketing resources in strategic planning are not analyzed. Therefore there is a need in the development or correction of strategic programs of Ukrainian enterprises in the conditions of high market uncertainty the identification of shortcomings of experience and limited resources for implementation of the principles of strategic planning and marketing because low literacy of enterprise management leads to the loss of market opportunities and the deterioration of the competitive position of enterprises in domestic and foreign markets. 
The purpose of the work. The main aim of the article is development of methodology and tools of marketing for solving problems of strategic planning in the conditions of economic instability, limited resources for management decision-making.

Presentation of the main research material. During the study, it is worth noting that strategic planning at the enterprise is defined as an organized process of strategic decision-making, the main contents of which is to compare own capabilities with the opportunities and threats of the external environment on the basis of the analysis of marketing information. The complexity of the problems arising in connection with this, determines the feasibility of using a systematic approach combined with the ideology of marketing as a conceptual framework for management in the market [2].

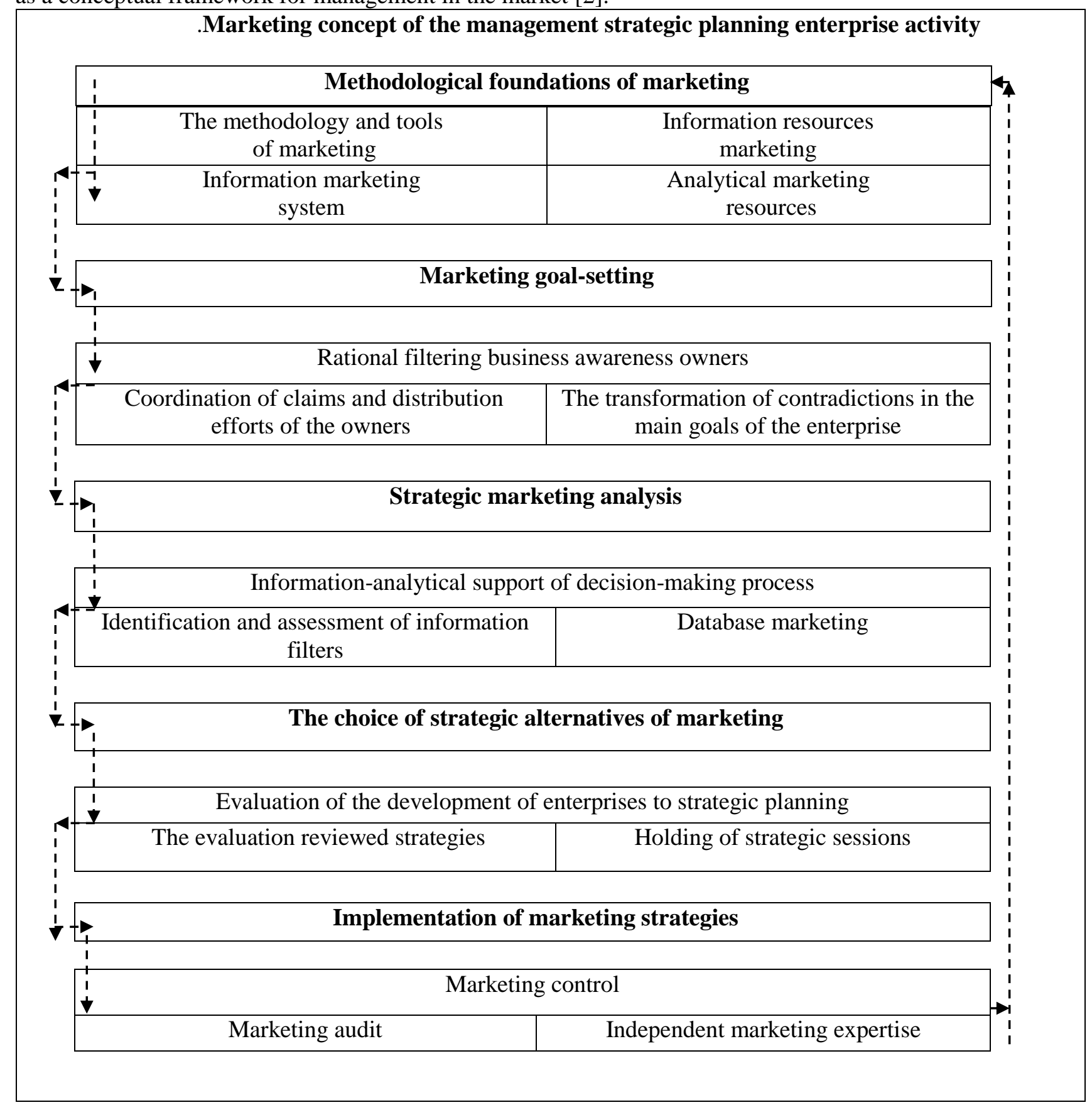

Fig. 1. The structure marketing concept of the management strategic planning enterprise activity* *Source: modified and compiled by the author based on the analysis of $[1-2,5-7]$ 
In our opinion, the marketing orientation of activity of the enterprise should be considered based on the following elements:

1) Ideology. Marketing orientation is perceived as an important part of the value system of the enterprise, as a base for the formation of vision, mission, goals, strategies, understanding of the necessity of market orientation as a prerequisite for effective performance.

2) Goal. The most important aspect of marketing orientation is the presences of marketing objectives in the overall system determine the goals of the enterprise: market share, consumer preferences, level of satisfaction, level of consolidation and increase customer loyalty, improvement of image.

3) Information. The company must have a reliable source of market information, relevant databases, means of rapid dissemination of this information, including through informal procedures in decisionmaking.

4) Organization. The orientation of the management system on marketing, in particular, the high status of leaders and organizations responsible for marketing activities.

5) Process. Market orientation in the processes of planning, control, incentives. A special role is played by features of the decision-making process (strategic and operational).

6) Tools. For the enterprise focused on marketing, characterized by intensive and diverse use of marketing strategies and activities in the area of commodity, price, marketing and communication policies.

Note that the marketing orientation in the strategic planning of the enterprise activities should be implemented based on the proposed marketing concept (see fig.1.), which consists in adapting and applying tested methods (tools) of marketing for the purpose of establishing and conducting a strategic planning process in Ukrainian enterprises.

Therefore, the use of system approach in strategic planning, in the final version, allows the solution of several special tasks as such : assess the adequacy of actions of the enterprise its external environments; formation and realization of the potential which based on aggregate resources of various kinds, who capable of solving the main tasks of the enterprise taking into account the real conditions of the external environment; the definition on the meta-system level the realization the function of determining the goals enterprise.

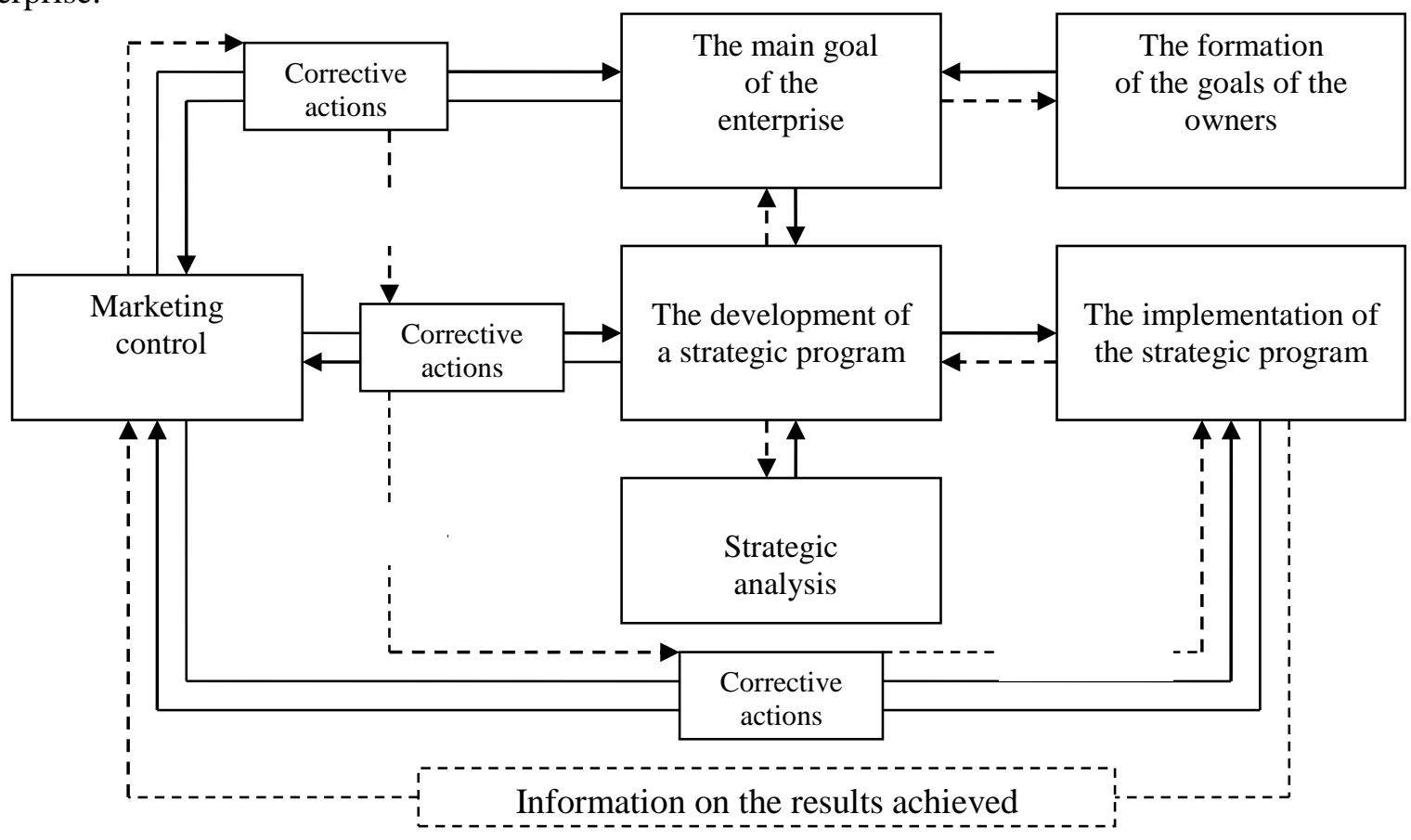

Fig. 2. Conceptual scheme of the management of strategic planning of enterprise* *Source: modified and compiled by the author based on the analysis of [5-7,9].

Except to determining the structure of marketing concept of the management strategic planning enterprise activity, we proposed the conceptual scheme of the management of strategic planning of 
enterprise, allowing you to guide the research process when making decisions in the direction of maximum compliance of the dynamics of external environment (see fig.2.).

In our opinion, the marketing concept of the management of strategic planning enterprise activity is able to implement the objectives of the enterprise based on the analysis of the structure and schemes managerial and financial decisions that will include the following stages:

1) Conduct of a description of the desired state (goals) of the enterprise, its description is implemented by defining desired values of main characteristics (indicators) of an enterprise: profit, market share, number of employees, productivity, profitability, the list of promising lines of business and other quantitative and qualitative characteristics.

2) Establishment of the main objectives of the enterprise. Large company has a lot of important goals and objectives, which have to able some degree of control over their implementation. Because the main goal of the company and also other her components is : product strategy, operational objectives, the achievement of which is controlled by explicitly stated indicators. The main goal is formulated as a compromise between the desires of owners and requirements of the marketing image of the company.

3) Conduct strategic analysis. Its most important components are market research of products enterprise, as well as the analyses internal situation in the enterprise. The main task of strategic analysis in planning is determining the competitive position of the enterprise in the markets of its products.

4) Development strategy. In the fourth stage to realized development strategic planning and transition plan from current state to the desired. Strategy can be considered as a link between the company's goals and line of conduct, chosen to achieve them.

5) Implementation of the strategy. Operational activities in accordance with the subdivision plans.

6) Marketing control. In the process of implementation of strategic plans the department of marketing is responsible for marketing control - process of continuous comparisons of results with objectives that are achieved by the firm and, if necessary, will realize develop the actions which adjust he, given the current situation at the market. Moreover, the level of correction may be subject to the enterprise strategy and goals.

Marketing control plays the role of feedback, which stabilizes the entire system, in this case, the strategic planning process and implementation of strategic plans.

Before the development of the strategy on the basis of the achievement of strategic objectives, it is necessary to assess the readiness of the enterprise to work in conditions of inevitable strategic changes.

In parallel with the research components of the marketing concept of the management strategic planning enterprise activity should propose a set of methods for determining the strategic level enterprise based on a preliminary assessment of the readiness of the management of the enterprise to work in conditions of strategic planning [5]. In our opinion, the strategic level of enterprises is based on characteristics, namely:

- the planning of activities, taking into account changes in the external environment;

- development of the complex strategies program and assessment of the market;

- the desire and goal of the owners of the company mutually consistent and documented;

- real mechanisms for the identification and localization of problems;

- implementation of a complex higher competitiveness;

- the adaptability of the enterprise to solve existing problems;

- the organizational distribution of strategic and operational management;

- orientation the management system on realization the strategic objectives of the enterprise;

- forming and use organizational structure for the intra-corporate consultancy;

- the use of external (third-party) consultants;

- continuous awareness of staff regarding long-term goals and plans;

- availability full-fledged company's department of marketing;

- high level of corporate culture.

The level of he manifestation in the activities of the company is proposed to estimate using the Delphi method. However, without loss of unity, this can lead to number of typical cases of violation of the balance of goals and in case of absence of a defined strategic level of enterprise will be to leads to organization problems. 
Considering the above characteristics of strategic enterprise-level, in the study we proposed to allocate 8 areas, which can be implemented using of the management of strategic planning enterprise activity based on the marketing concept, namely:

- The share of the market. Market stability of the enterprise is not determined by market share, she must correspond to the level of production capacity of enterprise. In addition, is important target market segmentation : while maintaining a nominal market share, it is advisable to focus on high-profit segments.

- Innovation - identifying new ways of doing business. The main requirement for investment activities by the enterprise - she must have long-term prospects at the market.

- Productivity. The company can set goals at the level of business results: increase productivity, reduce costs.

- Resources - needed to achieve goals (financial, material, human resources, marketing, branding). The company can increase resources for development and ensure competitive sustainability in the market.

- Income (profit) - often the declared purpose. Profitability in the short term can be in contradiction with the profitability in the long term.

- Managerial aspects of quality management. Is the basis for long-term success of the enterprise.

- Staff - job functions and work attitudes, including the level of corporate culture, measures of motivation.

- Social responsibility - the obligation of business to contribute to the welfare of society.

Note that strategic planning more related with development of the enterprise, which to requires a wider information horizon than for current activities. In addition, for effective development of enterprise necessary of better analytical capacity and adequately assess the impact of opportunities and threats. The lack of such analytical support for the marketing concept of the management strategic planning enterprise activity is a serious problem, as strategic decisions must be made on the basis of reliable and timely analytical information.

As the basis of systemic organization of information and analytical support of the marketing concept of the management strategic planning enterprise activity it is advisable to use an analytical function of marketing. Since the analytical function of marketing allows you to efficiently coordinate information and analytical work of the entire enterprise ideologically (assessing the level of compliance with sentences of the enterprise market demands), organizational (within the marketing division as a unified information center) and methodologically (including the general information direction of marketers) [6].

In the study justified methodical approach to setting up a marketing information system for the solution of analytical tasks for strategic planning. Thus, significantly expanded the possibility of using analytical functions of marketing that improves the quality of the strategic planning process.

It should be noted that the features of information-analytical support process management of the strategic planning based on the marketing concept is reflected in the proposed by us model of a marketing information system of enterprise (hereinafter - MMISE). Structure MMISE (see fig. 3.) must have meet of the system management of enterprise with considering specific external and internal information flows.

In the framework of the description of subsystems of the processing and analysis of information discusses of the following operations: structuring, compression, aggregation, presentation in visual form, statistical processing, a consistency check, evaluation of completeness, the search of dependencies, the extension and testing of hypotheses, prediction of future conditions and events [5,11].

In addition, the main feature of strategic decision-making under tight time and budget constraints is a necessity to conduct qualified professionals to intuitively-logic analysis of problems with a qualitative or quantitative assessment of expert judgment.

Therefore, MMISE is one of the main elements marketing concept of the management of strategic planning enterprise activity that provides verified and accurate information for effective implementation her results in practice, complementing proposed by us structure, scheme and stages. 


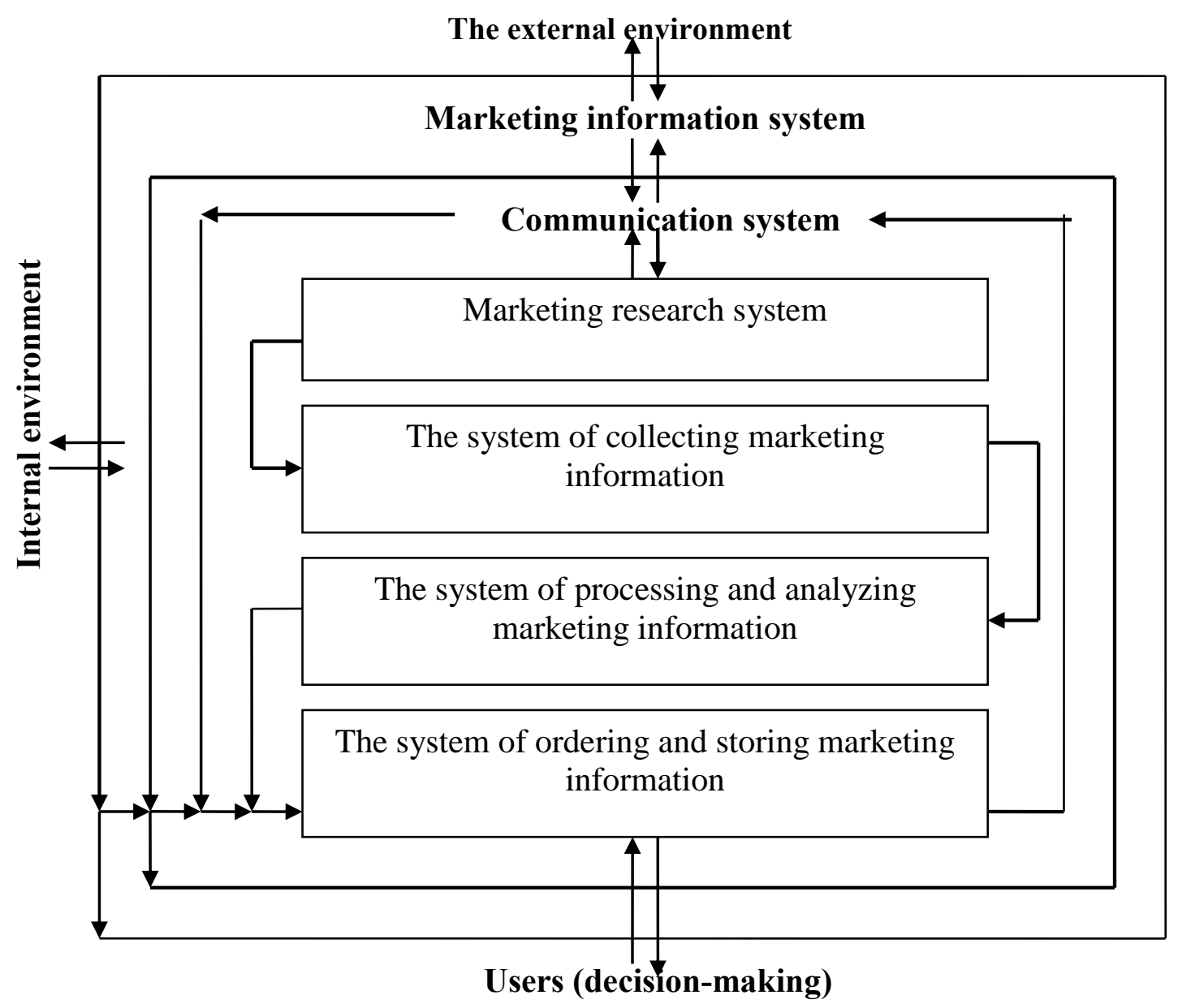

Fig. 3. Model of marketing information system of enterprise*

*Source: modified and compiled by the author based on the analysis of [3, 10-11]

Conclusions from the research. Therefore, formation of the marketing concept of the management strategic planning enterprise activity is a comprehensive, long-term process by which the entity identifies the desired results of activities in the market and builds its effective marketing strategy, which will be realized in practical activities together with ensuring effective process of internal management.

\section{Джерела та література}

1. Бутко М. П. Стратегічний менеджмент : навч. посіб. К. : Центр учбової літератури, 2016. 376 с.

2. Кіндрацька Г. І. Стратегічний менеджмент : навч. посіб. К. : Знання, 2006. 366 с.

3. Кузьмін О. С., Мельник О. Г. Основи менеджменту : підручник. Київ : Академвидав, 2013. 416 с.

4. Ліпич Л. Г., Морохова В. О., Московчук А. Т. Організація виробництва : навч. посіб. Луцьк : РВВ ЛДТУ, 2002. $256 \mathrm{c.}$

5. Макдональд М. Стратегическое планирование маркетинга. Санкт-Петербург : Питер, 2015. 320 с.

6. Крикавський Є.В., Косар Н.С., Мних О. Б., Сорока О. А. Маркетингові дослідження : навч. посіб. Львів: НУ «Львівська політехніка», Інтелект-Захід, 2014. 288 с.

7. Ламбен Ж.-Ж. Стратегический маркетинг : Европейская перспектива. Санкт-Петербург : Наука, 1996. $589 \mathrm{c}$.

8. Пічугіна Т. С., Ткачова С.С., Ткаченко О. П. Стратегічний менеджмент : навч. посіб. Харків : ХДУХТ, 2008. 215 c.

9. Подольчак Н. Ю. Стратегічний менеджмент : навч.-метод. посіб. Львів : Вид-во НУ «Львівська політехніка», 2016. 223 с.

10. Фатхутдинов Р. А. Стратегический менеджмент : учеб. Москва : ЗАО «Бизнес-школа «Интел-Синтез», 2015. 275 c. 
11. Шершньова 3. С. Стратегічне управління : навч. посіб. Київ : КНЕУ, 2004. 699 с.

\section{References}

1. Butko, M. P. (2016). Stratehichnyi menedzhment [Strategic management]. Kyiv : Centr uchbovoji literatury [in Ukrainian].

2. Kindratska, H. I. (2006) Stratehichnyi menedzhment [Strategic management]. Kyiv : Znannya [in Ukrainian].

3. Kuzmin, O. Ye., \& Melnyk, O.H. (2013) Osnovy menedzhmentu [Fundamentals of management]. Kyiv : Akademvydav [in Ukrainian].

4. Lipych, L.H., \& Morokhova, V.O., \& Moskovchuk, A.T. (2002) Orhanizatsiia vyrobnytstva [Organization of production]. Lutsk : RVV LDTU [in Ukrainian].

5. MakDonald, M. (2000) Stratehycheskoe planyrovanye marketynha [Strategic planning marketing]. Saint Petersburg: Pyter [in Russian].

6. Krykavskyi, Ye.V.\& Kosar, N.S. \& Mnykh, O.B. \& Soroka, O.A. (2004) Marketynhovi doslidzhennia [Marketing research]. Lviv: NU «Lvivska politekhnika» [in Ukrainian].

7. Lamben, Zh.-Zh. (1996) Stratehycheskyi marketynh [Strategic marketing]. Saint Petersburg: Nauka [in Russian].

8. Pichuhina, T. S. \& Tkachova, S.S. \& Tkachenko, O. P. (2008) Stratehichnyi menedzhment [Strategic management]. Kharkiv : KhDUKhT [in Ukrainian].

9. Podolchak, N.Yu. (2006) Stratehichnyi menedzhment [Strategic management]. Lviv : NU «Lvivska politekhnika» [in Ukrainian].

10. Fatkhutdynov, R.A. (2015) Stratehycheskyi menedzhment [Strategic management]. Moscow: ZAO «Byznesshkola «Yntel-Syntez» [in Russian].

11. Shershnova, Z.Ye. (2004) Stratehichne upravlinnia [Strategic management]. Kyiv : KNEU, [in Ukrainian].

Стаття надійшла до редакції 04.06.2020 р. 